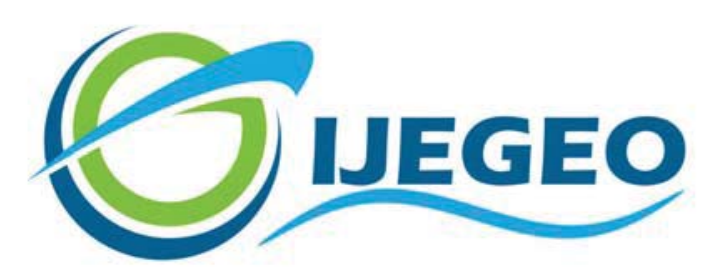

International Journal of Environment and Geoinformatics (IJEGEO) is an international, multidisciplinary, peer reviewed, open access journal.

\title{
Aegean Sea-Level Variability in the Past Half-Century Based on Tide Gauge Data
}

\section{Cem SENDURAN, Mehmet Sedat KAPDASLI}

\author{
Chief in Editor \\ Prof. Dr. Cem Gazioğlu \\ Co-Editors Prof. Dr. Dursun Zafer Şeker, Prof. Dr. Şinasi Kaya, \\ Prof. Dr. Ayşegül Tanık and Assist. Prof. Dr. Volkan Demir
}

Editorial Committee (March 2022)

Assoc. Prof. Dr. Abdullah Aksu (TR), Assoc. Prof. Dr. Uğur Algancı (TR), Assoc. Prof. Dr. Aslı Aslan (US), Prof. Dr. Levent Bat (TR), Prof. Dr. Paul Bates (UK), İrşad Bayırhan (TR), Prof. Dr. Bülent

Bayram (TR), Prof. Dr. Luis M. Botana (ES), Prof. Dr. Nuray Çağlar (TR), Prof. Dr. Sukanta Dash (IN), Dr. Soofia T. Elias (UK), Prof. Dr. A. Evren Erginal (TR), Assoc. Prof. Dr. Cüneyt Erenoğlu (TR), Dr. Dieter Fritsch (DE), Prof. Dr. Ç; Prof. Dr. Manik Kalubarme (IN), Dr. Hakan Kaya (TR), Assist. Prof. Dr. Serkan Kükrer (TR), Assoc. Prof. Dr. Maged Marghany (MY); Prof. Dr. Micheal Meadows (ZA), Prof. Dr. Nebiye Musaoğlu (TR), Prof. Dr. Masafumi Nakagawa (JP), Prof. Dr. Hasan Özdemir (TR), Prof. Dr. Chyssy Potsiou (GR), Prof. Dr. Erol Sarı (TR), Prof. Dr. Maria Paradiso (IT), Prof. Dr. Petros Patias (GR), Prof. Dr. Elif Sertel (TR), Prof. Dr. Nüket Sivri (TR), Prof. Dr. Füsun Balık Şanlı (TR), Dr. Duygu Ülker (TR), Prof. Dr. Seyfettin Tsaş (TR), Assoc. Prof. Dr. Ömer Suat Taşkın (TR), Assist. Prof. Dr. Tuba Ünsal (TR), Assist. Prof. Dr. Sibel Zeki (TR) 


\title{
Research Article
}

\section{Aegean Sea-Level Variability in the Past Half-Century Based on Tide Gauge Data}

\author{
Cem Senduran (D), M. Sedat Kabdasli iD
}

Istanbul Technical University, Institute of Graduate Studies, Coastal Sciences and Engineering Program, Istanbul, Turkey

* Corresponding author: C. Senduran

Received: 25.09 .2021

E-mail: cemsenduran@gmail.com

Accepted:30.11.2021

How to cite: Senduran and Kabdasli (2022). Aegean Sea-Level Variability in the Past Half-Century Based on Tide Gauge Data, International Journal of Environment and Geoinformatics (IJEGEO), 9(1): 162-169. doi. 10.30897/ijegeo.1014344

\begin{abstract}
Global sea-level rise induced by global warming has been growing in importance as a research topic in the past few decades. The Fifth Assessment Report of the Intergovernmental Panel on Climate Change (IPCC) has strongly emphasized a visually certain trend in the sea-level rise in the past two centuries. Many studies have addressed the trend in sea-level records, both in global and regional scale, as studying the trend renders it possible to make future predictions. The latest study of World Climate Research Programme Global Sea Level Budget Group determined the global sea-level rise between 1993-2018 as 3.1 mm/year. The Aegean as a regional sea is chosen for this study to compare if there are any similarities between the global tendency and the regional using tide gauge records of monthly mean sea-levels in selected 6 stations. The data used in this study were obtained from the Permanent Service for Mean Sea Level (PSMSL), which is an organization that collects and publishes tide gauge records from across the world. The gaps in the raw tide gauge data were imputed by Kalman filtering, the time series were decomposed by using STL decomposition and the loess smoothed trend lines were obtained. The data ranges of time series were divided into 2 segments (from 1969 to 1995 and from 1995 to the end date) and linear trends for each segment were determined as well as the whole duration for each station. Mann-Kendall, CoxStuart, and Spearman's Rho tests were applied on the datasets to detect statistically significant trends. The sea-level trends varied for each station and depending on the segment taken into consideration. 2 negative and 2 positive trends were obtained for the first segment. Positive trends changing from $1.6 \mathrm{~mm} /$ year to $7.5 \mathrm{~mm}$ /year with an average of $3.7 \mathrm{~mm} /$ year were determined for the second segment's results of all stations.
\end{abstract}

Keywords: Sea-level rise, trend analysis, STL decomposition, Aegean Sea

\section{Introduction}

The global warming and related atmospheric and climatic changes have been gaining increasing importance among the most urgent issues the world has to confront. Global sea-level rise is an internationally acknowledged topic bound to global warming and has been addressed not only by academics but also by governments because of its direct impact on coastal populations.

According to the study of World Climate Research Programme (WCRP) Global Sea Level Budget Group (2018), the global sea-level rise between the years 1993 and 2018 were determined as $3.1 \mathrm{~mm} /$ year $( \pm 0.3 \mathrm{~mm})$. Earlier, the Fifth Assessment Report of the Intergovernmental Panel on Climate Change (IPCC) declared that a global sea-level rise in the past 2 centuries was visually certain (IPCC, 2014; Foster and Brown, 2014). The lower and upper boundaries of predicted global sea-level rise by the year 2100 according to IPCC's report is between $0.28 \mathrm{~m}$ and $0.98 \mathrm{~m}$. The lower boundary comes from the extension of the linear regression for the $20^{\text {th }}$ century sea-levels; whereas, the upper boundary is calculated under the presence of a positive acceleration towards the future (Haigh, et al., 2014; Gazioğlu, 2018).

In a sea-level time series record, the trend component is regarded as to represent well the climate behavior because of being a low frequency signal (Visser, et al., 2015). Therefore, trend has been a topic of major interest by researchers for decades in studies relating global warming and sea-level rise (Woodworth, 1990; Douglas 1992; Alpar et al., 1997; Holgate and Woodworth, 2004; Church and White, 2006; Jevrejeva et al., 2006; Marcos and Tsimplis, 2007; Church et al., 2008; Gazioğlu et al., 2010; Simav et al., 2013; Dangendorf et al., 2015; Piecuch et al., 2019; Orlic et al., 2019; Çelik and Gazioğlu, 2020; Meli et al., 2021; Gehrels and Garrett, 2021).

However, the regional sea-level records can be different than the global tendency because freshwater input becomes more pronounced in estuary-like systems such as the Mediterranean and the Black Sea (Talley, et al., 2011) or because of the faster rate of heating and salinification, affecting the steric sea-level. In contrary to the global positive trend, the study by Tsimplis et al. (2011) combining steric sea-level for the period 1945-2002, and an atmospheric forcing model for the period 1958-2001 yielded negative trends across the Mediterranean Sea. Their results for the Eastern Mediterranean Basin were between $-0.9 \mathrm{~mm} /$ year and $0 \mathrm{~mm} /$ year for the steric sealevel; and between $-0.62 \mathrm{~mm} /$ year and $-0.70 \mathrm{~mm} /$ year for the atmospheric forcing model. The same study reports the observed rate of sea-level rise in the past century prior to its publication date as $1.2 \mathrm{~mm} /$ year, which shows the importance of time span of the trend calculation. The 
study of Cazenave, et. al. (2002) proves the importance of time span under scope by calculating a satellite altimetrybased trend of approximately $12.9 \mathrm{~mm} /$ year for the period of 1993-1998 in the Aegean Sea; whereas, tide gauge data of the past 2 decades revealed an approximately 0.62 $\mathrm{mm} /$ year trend in the same study. Fenoglio-Marc et. al. (2012) explained that the period of quick sea-level rise observed in the 90s was induced by both steric and mass components of the sea-level, which lost its rate of increase in the subsequent decade because of decreasing steric sealevel. Based on the model study of Criado-Aldeanueva, et. al. (2008), 55\% of the total sea-level trend in the Mediterranean is of steric origin, while the remaining accounts for the mass-induced component. Mediterranean and Aegean sea-levels have been investigated in several other studies in different temporal scales, a list of which are presented in Table 1.

Table 1 Other sea-level trend studies in the Mediterranean and Aegean Seas

\begin{tabular}{|c|c|c|c|c|}
\hline Study & Geographical coverage & Method & Time span & Trend (mm/year) \\
\hline \multirow{4}{*}{ Flemming and Woodworth (1988) } & Chios & \multirow{4}{*}{$\begin{array}{l}\text { Linear regression of } \\
\text { tide gauge data }\end{array}$} & \multirow{4}{*}{$1969-1983$} & 4.2 \\
\hline & Syros & & & -11.2 \\
\hline & Leros & & & -0.9 \\
\hline & Souda & & & -5.5 \\
\hline \multirow{2}{*}{ Vigo, et. al. (2005) } & \multirow{2}{*}{ Aegean Sea } & \multirow{2}{*}{ Satellite altimetry } & 1993-1999 & 1.6 \\
\hline & & & $1999-2003$ & -0.6 \\
\hline Criado-Aldeanueva, et. al. (2008) & Mediterranean Sea & Satellite altimetry & $1992-2005$ & 2.1 \\
\hline \multirow{3}{*}{ Fenoglio-Marc, et. al. (2012) } & \multirow{3}{*}{ Mediterranean Sea } & \multirow{3}{*}{$\begin{array}{l}\text { Satellite altimetry } \\
\text { combined with } \\
\text { numerical model }\end{array}$} & $1993-2002$ & 3.9 \\
\hline & & & $2002-2008$ & $0.8^{*}$ \\
\hline & & & $1993-2008$ & 2.0 \\
\hline
\end{tabular}

Except for the 4-year trend of $-0.6 \mathrm{~mm} /$ year reported by Vigo, et. al. (2005), all of the post 1990s trends demonstrate positive signs. Moreover, the study of Galassi and Spada (2014) has projected the future sealevel situation by 2040-2050 relative to 1990-2000 in the Mediterranean. Their result for the Aegean Sea suggests an increase between a minimum of $14 \mathrm{~cm}$ to $27.5 \mathrm{~cm}$ maximum.

The local sea-levels are monitored by countries via tide gauge stations and are collected and distributed by Permanent Service for Mean Sea Level (PSMSL, 2021). More information on the service and coverage of PSMSL can be found in Woodworth and Player (2003). The purpose of this study is to analyze the Aegean tide gauge records covered in PSMSL in order to examine whether or not the records are following a rising trend in parallel to the recently reported global sea-level.

\section{Materials and Methods}

The monthly mean sea-level (MMSL) tide gauge data were obtained from PSMSL web service (PSMSL, 2021; Holgate, et. al, 2013) for the selected locations from Greece (Table 2). These datasets are adjusted by PSMSL by reducing the monthly means measured in each station to a common datum and therefore forming the so-called "Revised Local Reference" (RLR) datasets. The RLR datum at each station in PSMSL database is defined to be $7000 \mathrm{~mm}$ below mean sea level, which was chosen to avoid negative numbers in the resulting RLR monthly mean values. The data does not involve adjustments due to glacial isostatic adjustment (GIA). Tamisiea and Mitrovica (2011) calculated the sea-level changes in the Aegean based on GIA to be between $0.15-0.40 \mathrm{~mm} / \mathrm{year}$ by using PSMSL's same tide gauge stations as in this study. The contribution of GIA is minor in comparison to that of mass and steric sea-level contributions (Galassi \& Spada, 2014).

Table 2 Selected tide gauge stations in the Aegean Sea

\begin{tabular}{ccc}
\hline Station & $\begin{array}{c}\text { Data range } \\
\text { (year) }\end{array}$ & $\begin{array}{c}\text { Data completeness } \\
(\%)\end{array}$ \\
\hline $\begin{array}{c}\text { Alexandrou } \\
\text { poli }\end{array}$ & $1969-2019$ & 89 \\
\hline Thessaloniki & $1969-2019$ & 89 \\
\hline Leros & $1969-2019$ & 83 \\
\hline Syros & $1969-2019$ & 86 \\
\hline Souda & $1969-2012$ & 96 \\
\hline Chios & $1969-2015$ & 85 \\
\hline
\end{tabular}

The raw data were analyzed using $\mathrm{R}$ Statistical Language and Environment (R Core Team, 2021). The gaps in the time series data were imputed by using a Kalman filtering application developed by Moritz and Bartz-Beielstein (2017). The completed time series plots of the selected stations are presented in Figure 1. The time series data were then decomposed to trend, seasonal, random components by using the R function "stl" based on Cleveland et.al. (1990). 


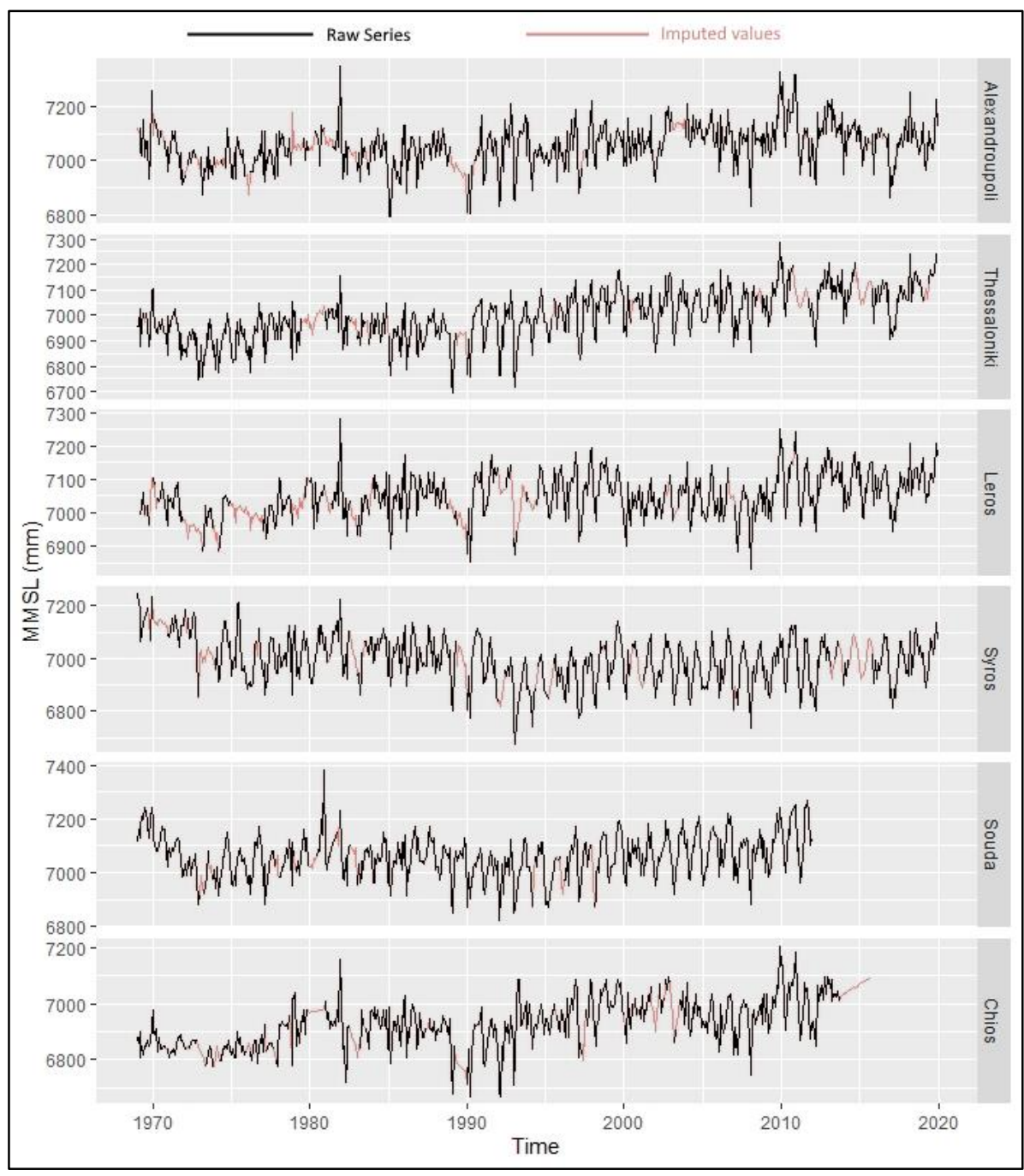

Fig. 1 Time series plots of MMSL data in the Aegean Sea

A reference period of 20 years (1974-1994) was selected to calculate the monthly mean values to be used as a baseline for calculating sea-level anomalies for each station (Table 3). It is highly recommendable to apply trend detection procedures before computing deterministic trends and corresponding slope coefficients (Fatichi, et al., 2009). Presence of trends were sought in the anomaly datasets for the full duration of the observations, as well as segmented sets dividing the time series into 2 level periods (first segment covers the years between 1969 and 1995, and the second covers the rest of the time series).

Detection of trends in hydrometeorological and sea-level data are commonly performed using Cox - Stuart (C-S) (Niedzielski and Kosek, 2011; Cox and Stuart, 1955), Mann - Kendall (M-K) (Feist, et. al., 2021; Hipel and McLeod, 1994), and Spearman's Rho (S) (Hipel and McLeod, 1994; Spearman, 1904) tests. For this study, these non-parametric tests were selected to avoid dependency to the distribution of data. In the case of detection of trends, linear regression models by least squares method (Wilks, 2011) were fitted to the anomalies data separately for each temporal segment, as well as the complete duration of observations. The loess trend obtained from the STL decomposition were also plotted along with the deterministic linear trends.

\section{Results}

C-S, M-K, and S tests were applied with a significance level at $\mathrm{p}$-value $<0.05$. According to the results presented in Table 4, Alexandroupoli and Thessaloniki stations do not show a significant trend in the first segment of their time series ( $p$-value>0.05). However, for the second segments and the complete duration, statistically significant trends are detected by all 3 test methods applied. Syros and Souda are represented by negative trends in the first segment as indicated by negative $\mathrm{Z}$ and Rho values of their respective $\mathrm{M}-\mathrm{K}$ and $\mathrm{S}$ tests results; whereas, Leros and Chios are represented by positive trends.

Examination of the second temporal segments reveal significant positive trends in all of the tide gauge stations but Syros. In Syros station, C-S test p-value (0.11) causes the acceptance of null hypothesis, which is the rejection of a monotonic trend in the dataset. Nevertheless, both M$\mathrm{K}$ and $\mathrm{S}$ test results suggest the presence of a positive trend. 
Table 3 Monthly mean sea-levels (mm) calculated for the baseline period of 1974-1994

\begin{tabular}{ccccccc}
\hline \hline Month & Alexandroupoli & Thessaloniki & Leros & Syros & Souda & Chios \\
\hline January & 6985.76 & 6901.33 & 7026.35 & 6947.08 & 6976.83 & 6882.57 \\
\hline February & 6984.47 & 6899.27 & 7028.13 & 6949.22 & 6985.33 & 6878.95 \\
\hline March & 6965.21 & 6859.20 & 6996.22 & 6911.64 & 6962.20 & 6852.82 \\
\hline April & 7026.03 & 6922.62 & 6991.35 & 6951.95 & 7007.69 & 6876.73 \\
\hline May & 7032.25 & 6931.14 & 7016.52 & 6968.49 & 7010.92 & 6886.54 \\
\hline June & 7048.76 & 6973.32 & 7027.03 & 7018.72 & 7045.33 & 6907.23 \\
\hline July & 7041.83 & 6972.31 & 7049.82 & 7063.75 & 7075.33 & 6908.71 \\
\hline August & 7036.63 & 6986.53 & 7068.82 & 7072.13 & 7094.86 & 6920.83 \\
\hline September & 7023.69 & 6984.90 & 7046.49 & 7046.71 & 7089.07 & 6899.20 \\
\hline October & 7033.57 & 6977.82 & 7039.24 & 7033.28 & 7096.00 & 6901.46 \\
\hline November & 7044.15 & 6970.05 & 7036.59 & 6997.03 & 7079.56 & 6894.02 \\
\hline December & 7053.04 & 6973.76 & 7055.36 & 6991.49 & 7081.28 & 6907.01 \\
\hline
\end{tabular}

Table 4 Time series trend test results of 6 tide gauge stations

\begin{tabular}{|c|c|c|c|c|c|c|c|c|}
\hline \multirow{2}{*}{ Data Set } & & \multicolumn{3}{|c|}{ Mann-Kendall } & \multicolumn{2}{|c|}{ Cox-Stuart } & \multicolumn{2}{|c|}{ Spearman's Rho } \\
\hline & & $\mathrm{Z}$ & p-value & Tau & $\mathrm{T}$ & p-value & Rho & p-value \\
\hline \multirow{3}{*}{ Alexandroupoli } & Complete series & 8.55 & $<10^{-15}$ & 0.23 & 7.14 & $<10^{-13}$ & 0.33 & $<10^{-16}$ \\
\hline & 1st segment & -1.11 & 0.27 & 0.04 & 0.78 & 0.43 & -0.06 & 0.26 \\
\hline & 2nd segment & 3.63 & $<0.0005$ & 0.14 & 2.8 & 0.005 & 0.20 & $<0.0005$ \\
\hline \multirow{3}{*}{ Thessaloniki } & Complete series & 14.67 & $<10^{-15}$ & 0.4 & 9.69 & $<10^{-15}$ & 0.57 & $<10^{-15}$ \\
\hline & 1st segment & 0.5 & 0.62 & 0.02 & 0.98 & 0.33 & 0.02 & 0.71 \\
\hline & 2nd segment & 6.53 & $<10^{-10}$ & 0.25 & 3.44 & 0.0005 & 0.36 & $<10^{-10}$ \\
\hline \multirow{3}{*}{ Leros } & Complete series & 8.90 & $<10^{-15}$ & 0.24 & 5.83 & $<10^{-8}$ & 0.36 & $<10^{-15}$ \\
\hline & 1st segment & 3.7 & 0.0002 & 0.14 & 3.25 & 0.001 & 0.22 & 0.0001 \\
\hline & 2nd segment & 3.6 & 0.0003 & 0.14 & 2 & 0.045 & 0.19 & 0.0008 \\
\hline \multirow{3}{*}{ Syros } & Complete series & -5.72 & $<10^{-7}$ & -0.15 & 7.14 & $<10^{-12}$ & -0.23 & $<10^{-8}$ \\
\hline & 1st segment & -8.83 & $<10^{-15}$ & -0.34 & 4.9 & $<10^{-6}$ & -0.48 & $<10^{-15}$ \\
\hline & 2nd segment & 4.42 & $<10^{-5}$ & 0.17 & 1.6 & 0.11 & 0.25 & $<10^{-4}$ \\
\hline \multirow{3}{*}{ Souda } & Complete series & 2.16 & 0.03 & 0.06 & 1.83 & 0.07 & 0.09 & 0.036 \\
\hline & 1st segment & -4.47 & $<10^{-5}$ & -0.17 & 4.31 & $<10^{-4}$ & -0.24 & $<10^{-4}$ \\
\hline & 2nd segment & 5.96 & $<10-8$ & 0.28 & 3.39 & 0.0007 & 0.41 & $<10-8$ \\
\hline \multirow{3}{*}{ Chios } & Complete series & 14.84 & $<10^{-15}$ & 0.42 & 11.04 & $<10^{-15}$ & 0.61 & $<10^{-15}$ \\
\hline & 1 st segment & 3.46 & 0.0005 & 0.13 & 2.74 & 0.006 & 0.22 & $<10^{-4}$ \\
\hline & 2nd segment & 5.23 & $<10^{-6}$ & 0.22 & 3.62 & 0.0002 & 0.33 & $<10^{-6}$ \\
\hline
\end{tabular}

A similar situation is accountable for the complete series at Souda station, where C-S test p-value (0.07) suggests rejecting an overall trend; whereas, the results of $\mathrm{M}-\mathrm{K}$ and $\mathrm{S}$ tests both point out the presence of a positive trend. Syros station's complete time series yielded a negative trend detectable by $\mathrm{M}-\mathrm{K}$ and $\mathrm{S}$ tests, with a statistical significance ( $\mathrm{p}$-value $<0.05$ ) for all of the 3 methods applied. All of the other stations demonstrate statistically significant positive trends in the complete temporal scales of their respective time series.

The anomalies of the loess trend component reveal differing information about the sea-level variations in the Aegean Sea per tide gauge station. The loess trend components of Syros and Souda appear to have lower levels in the end of their time series in comparison to the levels of their starting dates. The other 4 stations reveal increases in various magnitudes (Figure 2).

The sea-level trends of each station are separately examined in Figure 3. The anomalies of complete time series are represented in blue lines, loess smoothings are in purple, the deterministic linear trends covering the complete time periods are in black, and the segmented 20 25-year periodic linear trend lines are represented in brown and green colors respectively. Examination of segmented results separately reveal that in the first segment deterministic linear trend is negative for Syros ($7.5 \mathrm{~mm} /$ year) and Souda $(-3.7 \mathrm{~mm} /$ year $)$ and positive for Leros (1.6 mm/year) and Chios (1.7 mm/year). The trends calculated for Alexandroupoli and Thessaloniki are not statistically significant. 


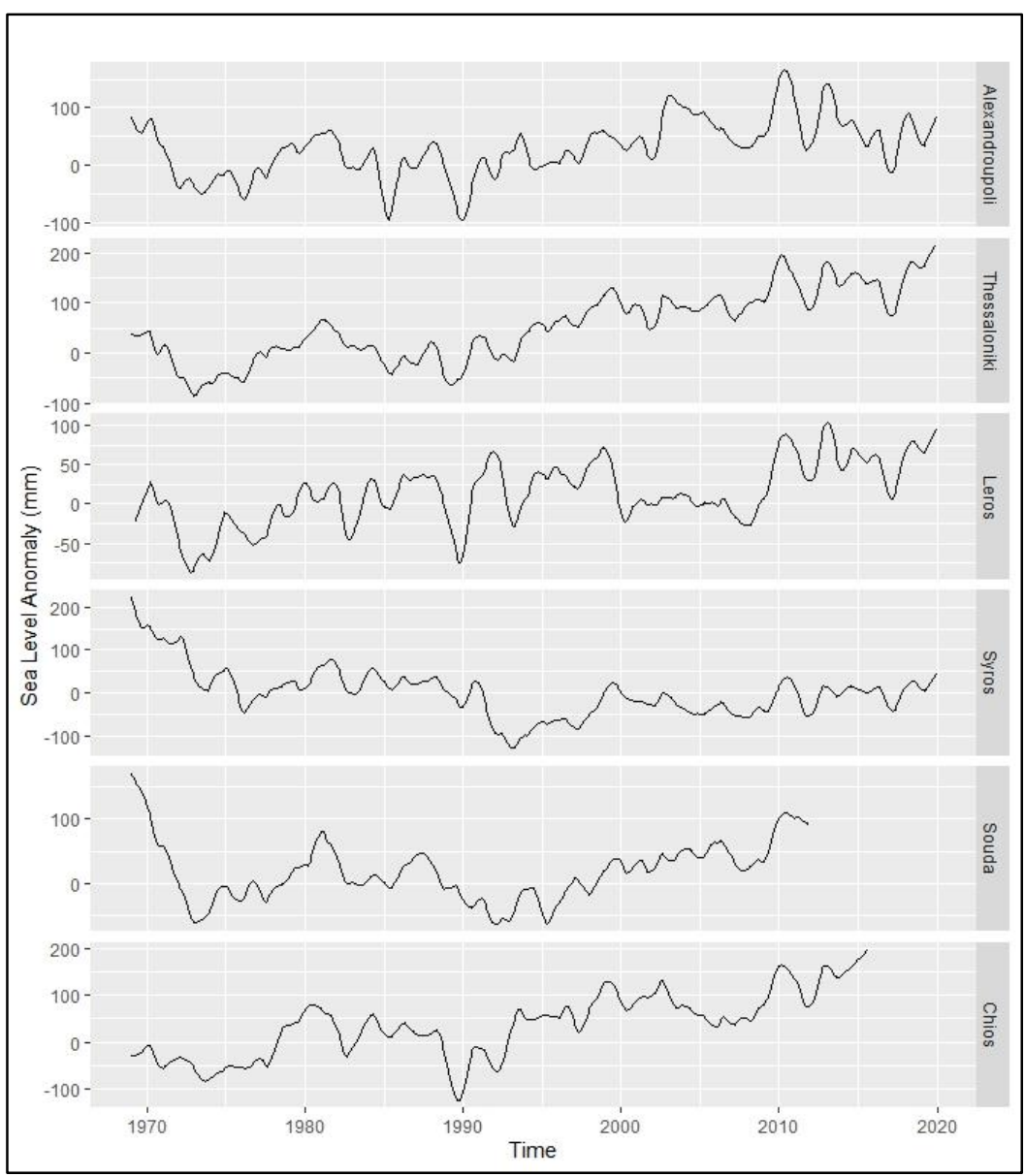

Fig. 2 Sea-level anomalies of STL decomposed trend components

Only in Leros and Chios stations both segments have positive deterministic trends. The trends for each segment in Leros station have the same slope, therefore being equal to the complete time period's deterministic trend (1.6 $\mathrm{mm} /$ year). The second segment for all the tide gauge stations have positive trends with different slopes each. In Alexandroupoli the slope is $2 \mathrm{~mm} /$ year, in Thessaloniki $4.5 \mathrm{~mm} /$ year, in Leros $1.6 \mathrm{~mm} /$ year, in Syros 3.1 $\mathrm{mm} /$ year, in Souda $7.5 \mathrm{~mm} /$ year, and in Chios 3.5 $\mathrm{mm} /$ year. Examination of the complete time periods yield positive trends for all stations but Syros. According to the overall trend line slopes covering the complete time series, the sea-level anomalies of Alexandroupoli is increasing with a rate of $1.8 \mathrm{~mm} /$ year, Thessaloniki is increasing by $3.9 \mathrm{~mm} /$ year, Leros is increasing by 1.6 $\mathrm{mm}$ /year, Syros is decreasing by $1.9 \mathrm{~mm} /$ year, Souda is increasing by $0.58 \mathrm{~mm} /$ year and Chios is increasing by 3.8 $\mathrm{mm} /$ year.

\section{Discussion and Conclusion}

The plots of time series anomalies, overlapped with deterministic linear trends and loess smoothing expose well the complexity of sea-level variations. Clearly, the loess smoothing in each plot uncovers periods of rises and falls in the sea-levels with a high degree of randomness and no obvious patterns except for the common minima observed in 1989-1990 (Alexandroupoli, Thessaloniki, Leros and Chios) and 1992-1993 (Syros and Souda).
The period before 90s, namely between 1960 and 1990, is marked as a period of positive NAO index, which is related to the sea-level decrease in that time span in the Mediterranean (Vigo, et. al., 2005; Tsimplis and Josey, 2001). The negative trends calculated by Flemming and Woodworth (1988) match with the Syros and Souda first temporal segment negative trends we calculated in this study. However, they explained the trends they calculated to be dominated by vertical land movements, rather than the steric sea-level component.

The increasing trends observed after the minima of early 90s are most likely related to the shift in the North Atlantic Oscillation (NAO) index which took place in that time (Mariotti, et. al. 2002) and partly related to the phenomena called Eastern Mediterranean Transient (EMT) induced by this shift (Lascaratos, et. al., 1999). In summary, the cooling until the NAO index shift and the salinity increase caused by the EMT afterwards, which carries the more saline Levantine waters into the Aegean, together caused the steric sea-level component to decrease until early 90 s. The increasing sea-levels afterwards are primarily related to the increasing temperatures as thermosteric component is dominant over halosteric component in the Mediterranean (Criado-Aldeanueva, et. al., 2008).

The deterministic linear trends results yielded different magnitudes of sea-level rise or falls, depending on location and the time period taken into consideration (i.e. 
Souda anomalies have a decreasing trend in the first segment but increasing in the overall). This, in fact, puts into question the objectivity of deterministic methods in time series analysis as it clearly depends on the time frame chosen to investigate the trend of a time series data as demonstrated by the earlier studies presented in Table 1 .
Statistically significant positive trends are detected for the second temporal segments in all of the tide gauge stations analyzed. This is most likely to be related to the increasing sea surface temperatures (SST) induced by the negative NAO index as the high correlation between SST and sealevel anomalies were revealed first by Cazenave, et. al. (2002) and then by Vigo, et. al. (2005).

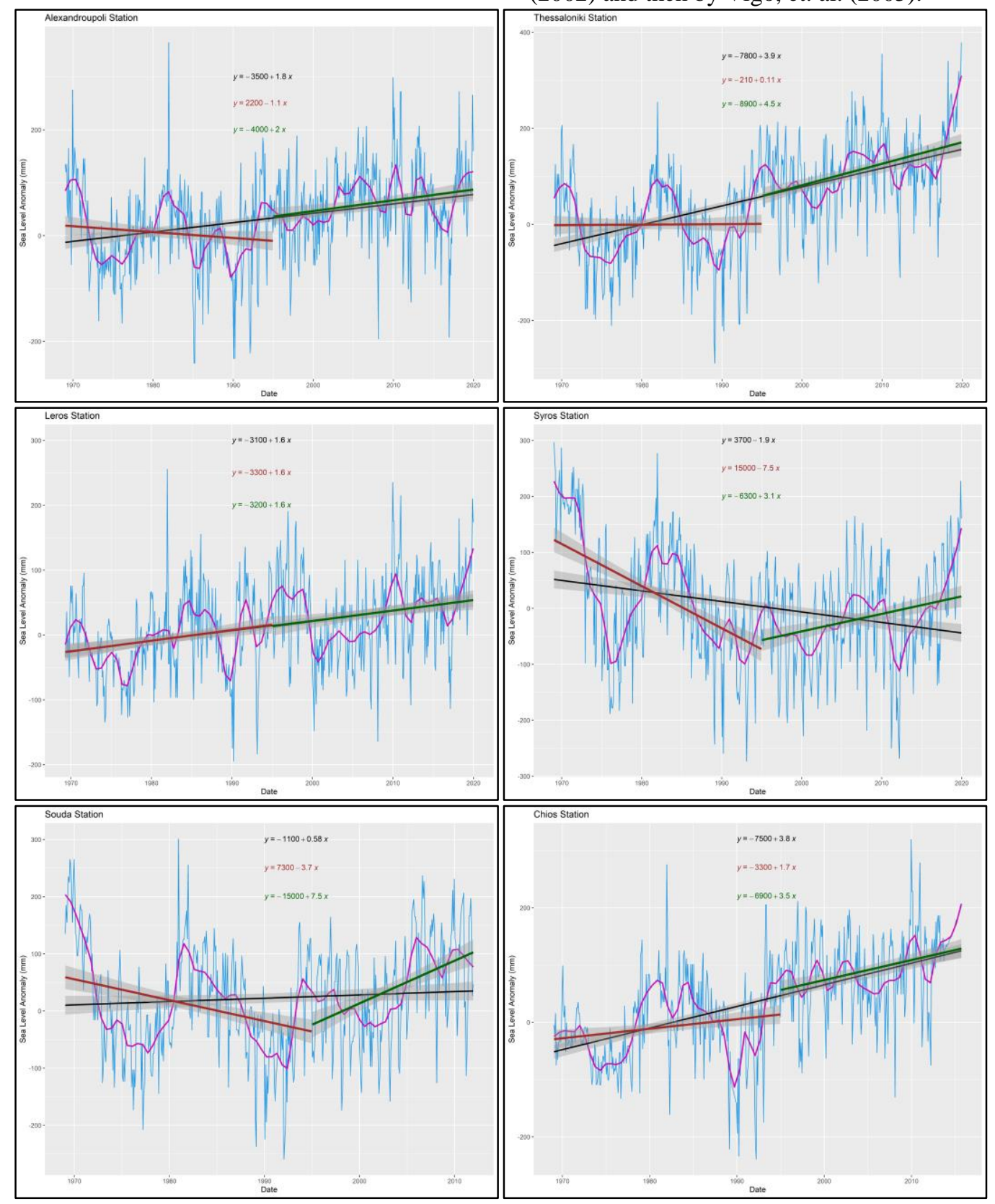

Fig. 3 Segmented and full-scale deterministic trends in each tide gauge station

The World Climate Research Programme (WCRP) Global Sea Level Budget Group's (2018) study results cover the global sea-level rise from 1993 to 2018, which is consistent with the second segment trend calculations in this study (1995-2019). The aforementioned study determined a global sea-level rise rate of $3.1 \mathrm{~mm} /$ year. The findings of this study in the second segment change from $1.6 \mathrm{~mm} /$ year (Leros island) to $7.5 \mathrm{~mm} /$ year (Souda in Crete island); while the average of all 6 stations equals to $1.6 \mathrm{~mm} /$ year in the Aegean Sea.
It can be concluded that the results show similarity for the selected time period. However, as demonstrated by the first segment trend results in this study, the sea-level dynamics of regional seas can as well show behaviors in the opposite direction of the global trend.

\section{Acknowledgements}

This study was supported by Istanbul Technical University, BAP Project Number: 39779. 


\section{References}

Alpar, B., Burak, S., Gazioğlu, C. (1997). Effect of weather system on the regime of sea level variations in İzmir Bay, Turkish Journal of Marine Sciences, 3(2),83-92

Cazenave, A., Bonnefond, P., Mercier, F., Dominh, K., Toumazou, V. (2002). Sea level variations in the Mediterranean Sea and Black Sea from satellite altimetry and tide gauges. Global and Planetary Change, 34(1-2), 59-86. doi:10.1016/S09218181(02)00106-6

Church, J. A., White, N. J. (2006). A 20th century acceleration in global sea-level rise. Geophysical Research Letters, 33(1), 94-97. doi:10.1029/2005GL024826

Church, J. A., White, N. J., Thorkild, A., Stanley Wilson, W., Woodworth, P. L., Domingues, C. M., . . . Lambeck, K. (2008). Understanding global sea levels: past, present and future. Sustainability Science, 3(1), 9-22. doi:10.1007/s11625-008-0042-4

Cleveland, R. B., Cleveland, W. S., McRae, J. E., Terpenning, I. (1990). STL: A Seasonal-Trend Decomposition Procedure Based on Loess. Journal of Official Statistics, 6(1), 3-33.

Cox, D. R., Stuart, A. (1955). Quick sign tests for trend in location and dispersion. Biometrika, 42, 80-95.

Criado-Aldeanueva, F., Del Rio Vera, J., GarciaLafuente, J. (2008). Steric and mass-induced Mediterranean sea level trends from 14 years of altimetry data. Global and Planetary Change, 60(3-4), 563-575. doi:10.1016/j.gloplacha.2007.07.003

Çelik, O. İ., Gazioğlu, C. (2020). Coastline Difference Measurement (CDM) Method. International Journal of Environment and Geoinformatics, 7(1), 1-5, doi.10. 30897/ijegeo.706792

Dangendorf, S., Marcos, M., Müller, A., Zorita, E., Riva, R., Berk, K., Jensen, J. (2015). Detecting anthropogenic footprints in sea level rise. Nature Communications, 6, 7849. doi:10.1038/ncomms8849

Douglas, B. C. (1992). Global Sea Level Acceleration. Journal of Geophysical Research, 97, 699-706. doi:10.1029/92JC01133; doi:10.1029/9

Fatichi, S., Barbosa, S. M., Caporali, E., Silva, M. E. (2009). Deterministic versus stochastic trends: Detection and challenges. Journal of Geophysical Research, 114, D18121. doi:10.1029/2009JD011960

Feist, S. E., Hoque, M. A., Islam, M. A., Ahmed, K. M., Fowler, M. (2021). Recent trends in inland water level change in coastal Bangladesh-implications of sea level rise in low-lying deltas. Global and Planetary Change, 206, 103639. doi:10.1016/j.gloplacha. 2021.103639

Fenoglio-Marc, L., Rietbroek, R., Grayek, S., Becker, M., Kusche, J., Stanev, E. (2012). Water mass variation in the Mediterranean and Black Seas. Journal of Geodynamics, 59-60, 168-182. doi:10.1016/ j.jog.2012.04.001

Flemming, N. C., Woodworth, P. L. (1988). Monthly mean sea levels in Greece during 1969-1983 compared to relative vertical land movements measured over different time scales. Tectonophysics, 148(1-2), 59-72. doi:10.1016/0040-1951(88)90160-6
Foster, G., Brown, P. T. (2014). Time and tide: analysis of sea level time series. Climate Dynamics, 45, 291308.

Galassi, G., Spada, G. (2014). Sea-level rise in the Mediterranean Sea by 2050: Roles of terrestrial ice melt, steric effects and glacial isostatic adjustment. Global and Planetary Change, 123, 55-66. doi:10.1016/j.gloplacha.2014.10.007

Gazioğlu, C. (2018). Biodiversity, Coastal Protection, Promotion and Applicability Investigation of the Ocean Health Index for Turkish Seas. International Journal of Environment and Geoinformatics, 5(3), 353-367, doi.10. 30897/ijegeo.484067

Gazioğlu, C. Burak, S.Z., Alpar, B., Türker, A. and Barut I.F. (2010). Foreseeable impacts of sea level rise on the southern coast of the Marmara Sea (Turkey), Water Policy, 12(6), 932-943

Gehrels, R., Garrett, E. (2021). Chapter 11 - Rising sea levels as an indicator of global change. In T. M. Letcher (Ed.), Climate Change (Third Edition) (pp. 205-217). Elsevier. doi:10.1016/B978-0-12-8215753.00011-6

Haigh, I. D., Wahl, T., Rohling, E. J., Price, R. M., Pattiaratchi, C. B., Calafat, F. M., Dangendorf, S. (2014). Timescales for detecting a significant acceleration in sea level rise. Nature Communications, 5, 1-11. doi:10.1038/ncomms4635

Hipel, K. W., McLeod, A. I. (1994). Time Series Modelling of Water Resources and Environmental Systems. Amsterdam, Netherlands: Elsevier.

Holgate, S. J., Woodworth, P. L. (2004). Evidence for coastal sea level rise during the 1990s. Geophysical Research Letters, 31(7), 2-5. doi:10.1029/ 2004GL019626

Holgate, S. J., Matthews, A., Woodworth, P. L., Rickards, L. J., Tamisiea, M. E., Bradshaw, E., . . Pugh, J. (2013). New Data Systems and Products at the Permanent Service for Mean Sea Level. Journal of Coastal Research, 29(3), 493-504. doi:10.2112 /jcoastres-d-12-00175.1

IPCC. (2014). Climate Change 2014: Synthesis Report. Contribution of Working Groups I, II and III to the Fifth Assessment Report of the Intergovernmental Panel on Climate Change. [Core Writing Team; Pachauri, R.K.; Meyer, L.A. (ed.)]. Geneva, Switzerland: IPCC.

Jevrejeva, S., Grinsted, A., Moore, J. C., Holgate, S. (2006). Nonlinear trends and multiyear cycles in sea level records. Journal of Geophysical Research, 111(9), 1-11. doi:10.1029/2005JC003229

Lascaratos, A., Roether, W., Nittis, K., Klein, B. (1999). Recent changes in deep water formation and spreading in the eastern Mediterranean Sea: a review. Progress in Oceanography, 44(1-3), 5-36. doi:10.1016/S00796611(99)00019-1

Marcos, M., Tsimplis, M. N. (2007). Forcing of coastal sea level rise patterns in the North Atlantic and the Mediterranean Sea. Geophysical Research Letters, 34, L18604. doi:10.1029/2007GL030641

Mariotti, A., Struglia, M. V., Zeng, N., Lau, K.-M. (2002). The Hydrological Cycle in the Mediterranean Region and Implications for the Water Budget of the Mediterranean Sea. Journal of Climate, 15(13), 1674- 
1690. doi:10.1175/1520-0442(2002)015\%3C1674. THCITM\%3E2.0.CO;

Meli, M., Olivieri, M., Romagnoli, C. (2021). Sea-Level Change along the Emilia-Romagna Coast from Tide Gauge and Satellite Altimetry. Remote Sensing, 13(1), 97. doi:10.3390/rs13010097

Moritz, S., and Bartz-Beielstein, T. (2017). imputeTS: Time Series Missing Value Imputation in R. R Journal 9.1. doi:10.32614/RJ-2017-009

Niedzielski, T., Kosek, W. (2011). Minimum time span of TOPEX/Poseidon, Jason-1 and Jason-2 global altimeter data to detect a significant trend and acceleration in sea level change. Advances in Space Research, 47(7), 1248-1255. doi:10.1016/j.asr. 2010.12.003

Orlić, M., Pasarić, M., Pasarić, Z. (2019). Mediterranean Sea-Level Variability in the Second Half of the Twentieth Century: A Bayesian Approach to Closing the Budget. In I. Vilibić, K. Horvath, and J. Palau (Eds.), Meteorology and Climatology of the Mediterranean and Black Seas. Birkhäuser, Cham: Pageoph Topical Volumes. doi:10.1007/978-3-03011958-4_15

Piecuch, C., Calafat, F., Dangendorf, S., Jorda, G. (2019). The Ability of Barotropic Models to Simulate Historical Mean Sea Level Changes from Coastal Tide Gauge Data. Survey in Geophysics, 40, 1399-1435. doi:10.1007/s10712-019-09537-9

PSMSL. (2021, January). Permanent service for mean sea level, data. Retrieved September 17, 2021, from http://www.psmsl.org/data/obtaining

R Core Team. (2021). R: A language and environment for statistical computing. $R$ Foundation for Statistical Computing. Vienna, Austria.

Spearman, C. (1904). "General Intelligence," Objectively Determined and Measured. The American Journal of Psychology, 15(2), 201-292. doi:10.2307/1412107

Simav, Ö., Şeker, DZ., Gazioğlu, C. (2013). Coastal inundation due to sea level rise and extreme sea state and its potential impacts: Çukurova Delta case, Turkish Journal of Earth Sciences 22 (4), 671-680.

Talley, L., Pickard, G., Emery, W. J., Swift, J. (2011). Descriptive Physical Oceanography: An Introduction (6th ed.). Boston, MA: Academic Press.

Tamisiea, M. E., Mitrovica, J. X. (2011). The moving boundaries of sea level change: Understanding the origins of geographic variability. Oceanography, 24(2), 24-39. doi:10.5670/oceanog.2011.25

Tsimplis, M. N., Josey, S. A. (2001). Forcing of the Mediterranean Sea by atmospheric oscillations over the North Atlantic. Geophys. Res. Lett., 28, 803-806.

Tsimplis, M., Spada, G., Marcos, M., Flemming, N. (2011). Multi-decadal sea level trends and land movements in the Mediterranean Sea with estimates of factors perturbing tide gauge data and cumulative uncertainties. Global and Planetary Change, 76(1-2), 63-76. doi:10.1016/j.gloplacha.2010.12.002

Vigo, I., Garcia, D., Chao, B. F. (2005). Change of sea level trend in the Mediterranean and Black seas. Journal of Marine Research, 63(6), 1085-1100. doi:10.1357/002224005775247607

Visser, H., Dangendorf, S., Petersen, A. C. (2015). A review of trend models applied to sea level data with reference to the "acceleration-deceleration debate". Journal of Geophysical Research: Oceans, 120(6), 3873-3895. doi:10.1002/2015JC010716

WCRP Global Sea Level Budget Group. (2018). Global sea-level budget 1993-present. Earth Syst. Sci. Data, 10, 1551-1590. doi:10.5194/essd-10-1551-2018

Wilks, D. S. (2011). Statistical methods in the atmospheric sciences. Academic Press.

Woodworth, P. L. (1990). A search for accelerations in records of European mean sea level. International Journal of Climatology, 10(2), 129-143. doi:10.1002/joc.3370100203

Woodworth, P. L., Player, R. (2003). The permanent service for mean sea level: an update to the $21 \mathrm{st}$ century. Journal of Coastal Research, 19, 287-295. 